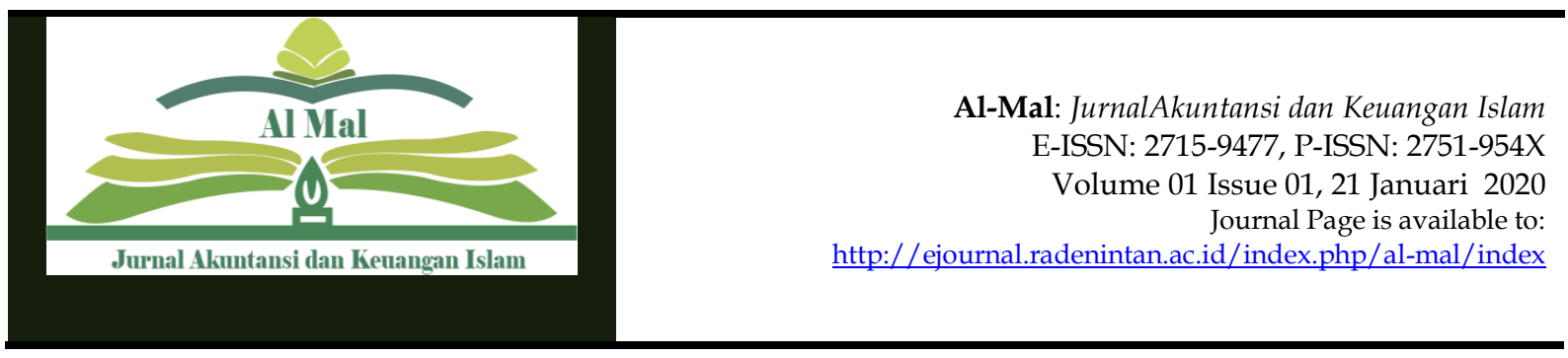

\title{
Pengaruh Komisaris Independen dan Dewan Pengawas Syariah Terhadap Manajemen Laba Pada Bank Umum Syariah Di Indonesia
}

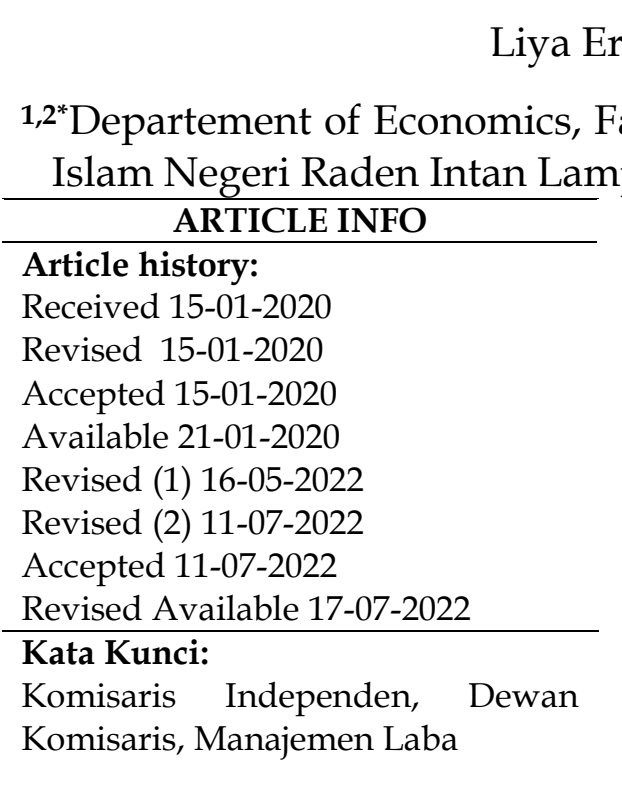

Paper type: Research paper

Please cite this article: Ernawati, L., \& Anggraeni A. "Pengaruh Komisaris Independen dan Dewan Pengawas Syariah Terhadap Manajemen Laba (Studi Pada Bank Umum Syariah Di Indonesia)" AlMal: Jurnal Akuntansi dan Keuangan Islam [ONLINE\}, Volume 01 Number 01 (Januari 21, 2020)

Cite this document:

Al-Mal 2th edition

*Corresponding author

e-mail:

liyaernawati@radenintan.ac.id

Page: 95-113

\begin{tabular}{l} 
ABSTRAK \\
\hline Penelitian ini bertujuan untuk menguji bagaimana \\
pengaruh komisaris independen dan dewan pengawas \\
syariah terhadap manajemen laba pada bank umum \\
syariah di Indonesia. Dalam penelitian ini menggunakan \\
metode pendekatan penelitian secara kuantitatif. Data \\
yang dikumpulkan untuk penelitian ini adalah data \\
sekunder yaitu data yang bersumber dari catatan yang \\
ada pada perusahaan dan dari sumber lainnya. Alat olah \\
data yang digunakan untuk menguji data sampel \\
penelitian yaitu SPSS 25 sebagai alat bantu untuk \\
menganalisis data. Hasil penelitian menunjukan bahwa \\
Komisaris independen yang diukur dengan \\
membandingkan jumlah komisaris independen terhadap \\
jumlah total dewan komisaris terbukti berpengaruh \\
negatif dan signifikan terhadap manajemen laba. Dewan \\
pengawas syariah yang diukur dengan jumlah rapat \\
dewan pengawas syariah berpengaruh positif dan tidak \\
signifikan terhadap manajemen laba. Keterbatasan pada \\
penelitian ini yaitu dari penggunaan variabel yang bisa \\
mempengaruhi manajemen laba, terdiri dari variabel \\
Dewan Komisaris Indpenden dan Dewan Pengawas \\
Syariah sehingga dapat memberikan peluang bagi peneliti \\
lainnya untuk melakukan penelitian yang sama dengan \\
menambahkan variabel yang lainnya. Impilkasi Dewan \\
komisaris independen dalam penelitian ini terbukti \\
mampu mengurangi manajemen laba, maka diharapkan \\
untuk mempertahankan agar dapat membatasi praktek \\
manajemen laba dan semakin banyak jumlah rapat \\
Dewan pengawas syariah maka akan semakin tinggi \\
praktek manajemen laba. \\
Al-Mal with Cc BY license. Copyright $\odot 2020$, the author(s) \\
\hline
\end{tabular}




\begin{abstract}
This study aims to examine how the influence of independent commissioners and sharia supervisory boards on earnings management in Islamic commercial banks in Indonesia. In this study using a quantitative research approach. The data collected for this research is secondary data, namely data sourced from existing records in the company and from other sources. Based on data analysis that has been done partially, the results of independent commissioners as measured by comparing the number of independent commissioners to the total number of commissioners are proven to have a negative and significant effect on earnings management. The independent board of commissioners in this study is proven to be able to reduce earnings management, so it is expected to maintain it in order to limit earnings management practices. The sharia supervisory board as measured by the number of sharia supervisory board meetings has a positive and insignificant effect on earnings management, the results of this study indicate that the more the number of sharia supervisory board meetings, the higher the earnings management practice. it is hoped that the sharia supervisory board will further improve supervision of the management so that the information contained in the financial statements is of better quality and quality
\end{abstract}

Keyword: Independent Commissioner, Board of Commissioners, Earnings Management

\title{
PENDAHULUAN
}

Undang-Undang No. 21 Tahun 2008 Tentang Perbankan Syariah menjelaskan bahwa Perbankan Syariah merupakan segala sesuatu yang menyangkut tentang Bank Syariah dan Unit Usaha Syariah, mencakup kelembagaan, kegiatan usaha, serta cara dan proses dalam melaksanakan kegiatan usaha (Siti Nurjanah:2017). Berdasarkan statistik Perbankan Syariah yang dihimpun oleh Otoritas Jasa Keuangan (OJK) per September 2018, di Indonesia terdapat 14 Bank Umum Syariah, 34 Unit Usaha Syariah dan 168 Bank Pembiayaan Rakyat Syariah (OJK:2018 hal.5). Dalam pengungkapan laporan keuangan perbankan syariah harus dilakukan secara transparan karena informasi yang sesuai dan memadai begitu penting dalam pengambilan keputusan bagi pihak-pihak yang berkepentingan di perbankan syariah. Salah satu bentuk pertanggungjawaban bank yaitu melalui laporan keungan maupun laporan tahunan bank. Di mana proses pelaporan tersebut harus terbebas dari manipulasi atau rekayasa 
manajemen, sehingga tidak ada pihak-pihak yang merasa dirugikan (Euis Nurhayati dkk, 2019:45). Dalam penyedian laporan keuangan, perbankan syariah wajib untuk mematuhi standar yang telah ditentukan Ikatan Akuntansi Indonesia (IAI). Manfaat utama dari harmonisasi standar akuntansi pelaporan keuangan adalah pemahaman yang lebih baik atas laporan keuangan oleh pengguna yang berasal dari berbagai negara (Muhammad Ash-Shiddiqy, 2019:165).

Penyusunan laporan keuangan manajemen perusahaan banyak menggunakan konsep akrual basis karena dapat memberikan informasi yang lebih baik tentang kinerja ekonomi perusahaan dibandingkan informasi yang dihasilkan dari cash basis. Dengan menggunakan merode akrual basis dapat memudahkan manajer perbankan syariah dalam mengelola laba perbankan syariah tanpa menyimpang dari aturan Standar Akuntansi Keuangan Yang Berlaku Umum karena telah memilih metode akuntansi yang sesuai. Apabila target perbankan syariah tidak tercapai maka pihak manajer perbankan syariah dapat mengubah komponen-komponen akrual yang dilaporkan. Manajemen laba riil melalui arus kas operasi dapat dilakukan dengan pengelolaan penjualan melalui pemberian potongan harga dan kelonggaran jatuh tempo pembayaran guna meningkatkan penjualan. Manajemen laba riil melalui biaya produksi dilakukan dengan melakukan produksi yang berlebih, sehingga menurunkan harga pokok penjualan dan meningkatkan nilai laba akan meningkat (Rina Trisnawati, :349). Adanya tindakan manjemen laba (earning management) di dalam suatu perusahaan yang dilakukan oleh pihak pengelola perusahaan (agent) dan pihak Penjelasanpenjelasan berikut adalah instruksi lebih lanjut untuk penulis. pemilik atau berkepentingan (principal) merupakan masalah yang sering terjadi dalam perusahaan (Novi Lidiawati dkk:2016). 
Beberapa faktor yang mempengaruhi tingkat pengungkapan tanggung jawab sosial diantaranya adalah komposisi independen, Dewan Pengawas Syariah (DPS), kepemilikan institusional dan profitabilitas (Rena Mustari Mokoginta dkk, 2019:56). Melalui kebijakan yang diambil agen sebagai pengelola perusahaan dapat melakukan tindakan yang menguntungkan diri sendiri dengan dinilai kinerjanya baik oleh pihak pemilik sehingga akan mendapatkan bonus atau naik jabatan dari kinerjanya tersebut. Sedangkan prinsipal selaku pemilik perusahaan hanya dapat mengawasi jalannya perusahaan melalui informasi yang diberikan agen. Informasi yang disajikan oleh pihak agen tidak sesuai dengan kondisi perusahaan yang sesungguhnya. Keterkaitan agency theory dalam penelitian ini adalah karena manajemen laba merupakan bentuk agency problem. Sebuah perusahaan secara periodik menyiapkan laporan keuangan untuk pihakpihak yang berkepentingan seperti pemegang saham, investor dan pemerintah. Laporan keuangan berfungsi untuk menyediakan informasi yang menyangkut posisi keuangan, kinerja, serta perubahan posisi keuangan (arus kas) suatu entitas yang bermanfaat bagi sejumlah besar pemakai dalam pengambilan keputusan ekonomi (Muhammad Izazi dkk, 2018:334).

Manajemen laba terjadi karena adanya assimetric information antara manajemen selaku agen dan pemilik perusahaan selaku principle.(Tulus Suryanto:2014). Selain itu, manajemen laba telah menjadi budaya perusahaan (corporate culture) yang dipraktikkan semua perusahaan di dunia. Aktivitas ini tidak hanya di negara-negara dengan sistem bisnis yang belum tertata, namun juga dilakukan oleh perusahaan-perusahaan di negara yang sistem bisnisnya telah tertata, seperti Indonesia (Ahadiah Agustina, 2019:27). Keberadaan dewan komisaris independen diharapkan dapat meminimalisir praktik manajemen laba karena dewan komisaris independen berfungsi sebagai pemisah kepentingan antara pemegang saham dengan manajemen (Happy Dwi Oktaviani, 2016:4). 
Perbankan syariah sebagai lembaga keuangan yang bergerak atas dasar prinsip-prinsip syariah tidak seharusnya melakukan aktivitas rekayasa dalam bentuk apapun termasuk dalam menyusun laporan keuangan. Maka dari itu laporan keuangan yang dibuat dapat membantu dalam pengambilan keputusan ekonomis serta sebagai sarana pertanggungjawaban yang tidak boleh disajikan untuk menguntungkan beberapa pihak (Imaniar Agustin \& Dian Filianti, 2021:510). Dalam hal ini, industri keuangan syariah juga perlu meningkatkan kualitas dari segala aspek yang bisa menarik perhatian investor asing ke pasar industri keuangan syariah tersebut yang salah satunya adalah perbankan syariah (Mahdalena, 2017:2).

\subsection{Grand Teori}

Teori keagenan (agency theory) merupakan suatu kondisi yang terjadi pada suatu perusahaan dimana pihak manajemen sebagai pelaksana yang disebut sebagai agen dan pemilik modal (owner) sebagai prinsipal membangun suatu kontrak kerjasama yang disebut dengan "nexus of contract", kontrak kerjasama ini berisi kesepakatan-kesepakatan yang menjelaskan bahwa pihak manajemen perusahaan harus bekerja secara maksimal untuk memberikan kepuasan yang maksimal seperti profit yang tinggi kepada pemilik modal atau owner (Irham Fahmi:2014).

Pihak agen menguasai informasi secara maksimal (full information) dan disisi lain pihak prinsipal memiliki keunggulan kekuasaan (discretionary power) atau memaksimalkan kekuasaan sehingga kedua pihak ini sama-sama memiliki kepentingan pribadi (self-interest) dalam setiap keputusan yang diambil, salah satu efek yang jauh biasa terjadi adalah perolehan deviden yang rendah yang akan diterima oleh prinsipal karena faktor perubahan metode yang dilakukan oleh agen (Tulus Suryanto:2014). Hal ini terkait dengan permasalahan tingkat akuntabilitas dan transparansi penggunaan dana nasabah/Investment Account Holder (IAH) dan pemilik perusahaan (Kodriyah dkk, 2017:59). Masalah agensi tidak hanya terjadi antara 
pemegang saham dengan agen, tetapi juga terjadi antara pemegang saham pengendali dengan pemegang saham non pengendali (Laras Clara Intia, 2021:47).

Watts dan Zimmerman dalam teori agensi juga dikenal adanya informasi yang tidak seimbang yang disebut Asimetri informasi (information asymmetry). Asimetri informasi ini muncul sebagai akibat adanya distribusi informasi yang tidak sama antara pemilik dan manajer. Menurut Jensen dan Meckling menyatakan bahwa permasalahan yang terjadi antara prinsipal dan agen adalah sebagai berikut (Dalam Tulus Suryanto:2014)

1. Moral Hazard

Moral Hazard merupakan permasalahan yang timbul jika agen tidak melaksanakan hal-hal yang disepakati bersama dalam kontrak kerja, atau menyeleweng dari kesepakan yang telah ditetapkan.

2. Adverse selection

Adverse selection merupakan suatu tindakan dimana prinsipal tidak dapat mengetahui apakah suatu kepentingan yang diambil oleh agen benar-benar didasarkan atas informasi yang telah diperolehnya atau terjadi sebagai sebuah kesalahan tugas.

Dalam pelaksanaannya, terjadi konflik kepentingan antara agen dan principal tersebut, dimana agen memiliki kepentingan untuk dirinya sendiri yaitu mendapatkan bonus atas kinerja perusahaan, sehingga manajemen selaku agen akan menge-lola laba untuk kepentingan sendiri. Adanya konflik kepentingan tersebut, dibutuhkan adanya fungsi pengawasan sehingga dapat meminimalisir konflik kepentingan yang terjadi (Amirul Arif \& Agus Purwanto, 2020:185).

\subsection{Definisi Manajemen Laba}

Manajemen laba merupakan intervensi yang dilakukan manajer dalam proses penyusunan laporan keuangan bagi pihak eksternal sehingga dapat meratakan, menaikan, dan menurunkan 
pelaporan laba, dimana manajemen dapat menggunakan kelonggaran penggunaan metode akuntansi, membuat kebijakan-kebijakan (discreationary) yang dapat mempercepat atau menunda biaya-biaya dan pendapatan, agar laba perusahaan lebih kecil atau lebih besar sesuai dengan yang diharapkan (Islahuzzaman:2013).

Manajemen laba diduga muncul atau dilakukan oleh manajer atau para pembuat laporan keuangan dalam proses pelaporan keuangan suatu organisasi karena mereka mengharapkan suatu manfaat dari tindakan yang dilakukannya (Maya Indriastuti, 2012:533). Tindakan manajemen laba dapat diminimalisir melalui suatu mekanisme monitoring yang bertujuan untuk menyeimbangkan berbagai kepentingan dalam perusahaan, terutama kepentingan antara pihak manajer dengan pihak pemilik modal (Triana Novitasari, 2019:86).

Manajemen laba tidak selalu dikaitkan dengan upaya untuk memanipulasi data atau informasi akuntansi, tetapi lebih condong dikaitkan dengan pemilihan metode akuntansi yang secara sengaja dipilih oleh manajemen untuk tujuan tertentu dalam batasan GAAP. Pihak-pihak yang kontra terhadap manajemen laba, menganggap bahwa manajemen laba merupakan pengurangan dalam keandalan informasi yang cukup akurat mengenai laba untuk mengevaluasi return dan resiko portofolionya (Tulus Suryanto, 2014:91).

\subsection{Definisi Komisaris Independen}

Komisaris Independen merupakan mekanisme internal Corporate Governance yang menjamin pada disiplin manajer perusahaan. Corporate Governance bertujuan menciptakan nilai tambah bagi stakeholder (Islahuzzaman:2013) . Komisaris Independen merupakan anggota Komisaris yang berasal dari luar Emiten atau Perusahaan Publik, tidak mempunyai saham baik langsung ataupun tidak langsung pada Emiten atau Perusahaan Publik, tidak mempunyai hubungan afiliasi dengan Emiten atau Perusahaan 
Publik, Komisaris, Direksi, atau Pemegang Saham Utama Emiten atau Perusahan Publik, dan tidak mempunyai hubungan usaha baik langsung maupun tidak langsung yang berkaitan dengan kegiatan usaha Emiten atau Perusahaan Publik (Rahmawati:2012). Dewan komisaris independen diukur berdasarkan persentase jumlah dewan komisaris independen terhadap jumlah total komisaris yang ada dalam susunan dewan komisaris perusahaan (Hikmah Is'ada Rahmawati, 2013:12). Tugas utama dari komisaris independen ini diantaranya menilai dan mengarahkan strategi perusahaan, kebijakan pengendalian risiko, anggaran tahunan, dan rencana usaha; menilai sistem penetapan remunerasi para pejabat yang memegang posisi kunci; memantau dan mengatasi konflik kepentingan; dan memantau proses keterbukaan dan efektifitas komunikasi dalam perusahaan (Clarissa Taco \& Venttje Ilat, 2016:875).

\subsection{Definisi Dewan Pengawas Syari'ah}

Bagi bank yang melakukan kegiatan usaha berdasarkan prinsip syariah, harus memiliki dewan pengawas syariah, yaitu badan independen yang bertugas melakukan pengarahan (directing), pemberian konsultasi (consulting), melakukan evaluasi (evaluating), dan pengawasan (supervising) kegiatan bank syariah dalam rangka memastikan kegiatan usaha bank syariah tersebut mematuhi (compliance) terhadap prinsip syariah sebagaimana telah ditentukan oleh fatwa dan syariah Islam (Tulus Suryanto:2014). Dewan pengawas syariah yang menjabat pada beberapa institusi finansial Islam dapat meningkatkan pengungkapan informasi karena dapat melakukan perbandingan pada pelaporan perusahaan sehingga dapat mengetahui pelaporan manakah yang terbaik (Ratna Aditya Ningrum dkk, 2013).

Selain itu, Menilai aspek syariah terhadap pedoman operasional dan produk yang dikeluarkan bank, memberikan opini dari aspek syariah terhadap pelaksanaan operasional bank secara keseluruhan dalam laporan 
publikasi bank dan mengkaji produk dan jasa baru yang belum ada fatwa untuk dimintakan fatwa kepada DSN (Anthon Indra Jaa \& M. Rasuli, 2021:46). Sehingga memperkuat alasan utama dibentuknya DPS pada lembaga perbangkan syaraiah adalah untuk memastikan seluruh aktifitasaktifitas serta prinsip-prinsip yang dilakukan perbankan syariah tidak melenceng dari aturan yang ada. DPS juga menjadi kontrol yang kuat bagi perusahaan (Jumaini Azizah \& Erinos NR, 2020:2558). Dewan pengawas syariah yang besar akan menjalankan tugas untuk memastikan kepatuhan bank syariah terhadap hukum dan prinsip Islam lebih baik, dan diharapkan bahwa mereka juga akan berperan dalam mewajibkan aktivitas sosial dan juga pengungkapan Islamic Social Reporting bank syariah (Febry Ramadhani dkk, 2016).

\section{METODOLOGI PENELITIAN}

Dalam penelitian ini menggunakan metode pendekatan penelitian secara kuantitatif. Data yang dikumpulkan untuk penelitian ini adalah data sekunder yaitu data yang bersumber dari catatan yang ada pada perusahaan dan dari sumber lainnya yaitu dengan mengadakan studi kepustakaan dengan mempelajari buku-buku yang ada hubungannya dengan objek penelitian atau dapat dilakukan dengan menggunakan data dari Biro Pusat Statistik.( Danang Suntoyo:2016)

Populasi adalah sekelompok kejadian atau segala sesuatu yang mempunyai karakteristik tertentu. (Sugiyono:2014) Populasi dalam penelitian ini adalah Bank Umum Syariah (BUS) di Indonesia periode tahun 2014-2017. Jumlah populasi dalam penelitian ini adalah 14 Perbankan Syariah yang terdaftar pada Bank Umum Syariah di Indonesia selama 4 tahun berturut-turut.

Sampel adalah sebagian kecil dari jumlah karakteristik yang dimiliki oleh populasi. (J.Supranto:2007) Sedangkan metode pengumpulan sampel 
yang digunakan dalam penelitian ini adalam Purposive Sampling, dan indikator yang diguakan harus sesuai dengan kriteria yang digunakan.

\section{HASIL DAN PEMBAHASAN}

Hasil Perhitungan Regresi Model Random Effect

\begin{tabular}{|c|c|c|c|}
\hline Variabel & Koefisien & t- Statistik & Signifikan \\
\hline Konstanta & 0.609757 & 1.922924 & 0.0622 \\
\hline KI & -0.792735 & -2.470884 & 0.0182 \\
\hline DPS & 0.006573 & 0.421225 & 0.676 \\
\hline \multicolumn{4}{|l|}{ Random Effects (Cross) } \\
\hline \multicolumn{4}{|l|}{$\mathrm{BSM}=0.000000$} \\
\hline \multicolumn{4}{|l|}{ MUA $=0.000000$} \\
\hline \multicolumn{4}{|l|}{$\mathrm{BRI}=0.000000$} \\
\hline \multicolumn{4}{|l|}{$\mathrm{BNI}=0.000000$} \\
\hline \multicolumn{4}{|l|}{$\mathrm{PNN}=0.000000$} \\
\hline \multicolumn{4}{|l|}{$\mathrm{BKP}=0.000000$} \\
\hline \multicolumn{4}{|l|}{$\mathrm{BJB}=0.000000$} \\
\hline \multicolumn{4}{|l|}{$\mathrm{VIC}=0.000000$} \\
\hline \multicolumn{4}{|l|}{$\mathrm{BCA}=0.000000$} \\
\hline \multicolumn{4}{|l|}{ MEG $=0.000000$} \\
\hline \multicolumn{4}{|l|}{ R-Squared $=0.147700$} \\
\hline Adjusted R-Squareed $=0.101630$ & & & \\
\hline
\end{tabular}

Sumber: Output Eviews 9, Data sekunder diolah 2019.

Berdasarkan hasil perhitungan regresi model Random Effect yang ditunjukan pada tabel 4.8 maka diperoleh hasil persamaan model regresi sebagai berikut :

$$
\mathrm{DA}=0.609757-0.792735\left(X_{1}\right)+0.006573\left(X_{2}\right)
$$

Keterangan :

$\mathrm{DA}=$ Manajemen Laba

$\mathrm{X}_{1}=$ Komisaris Independen $(\mathrm{KI})$

$\mathrm{X}_{2}=$ Dewan Pengawas Syariah (DPS)

Dari hasil persamaan regresi diatas, maka dapat dijelaskan sebagai berikut : 
a. Koefisien regresi variabel Komisaris Independen $\left(X_{1}\right)$ adalah sebesar 0,792735, artinya jika variabel independan lain nilainya tetap dan nilai dari Komisaris Independen $\left(X_{1}\right)$ mengalami kenaikan 1, maka nilai dari manajemen laba akan mengalami penurunan sebesar -0,792735. Begitupun sebaliknya, jika variabel independen lain nilainya tetap dan nilai dari Komisaris Independen mengalami penurunan 1, maka nilai dari variabel manajemen laba akan mengalami kenaikan sebesar 0,792735 .

b. Koefisien regresi variabel Dewan Pengawas Syariah $\left(X_{2}\right)$ adalah sebesar 0,006573, artinya jika variabel independen lain nilainya tetap dan nilai dari dewan pengawas syariah mengalami kenaikan 1, maka nilai dari manajemen laba akan mengalami kenaikan sebesar 0,006573. Begitupun sebaliknya, jika variabel independen lain nilainya tetap dan nilai dari dewan pengawas syariah mengalami penurunan 1, maka nilai dari variabel manajemen laba akan mengalami penurunan sebesar 0,006573.

1. Hasil uji t (Parsial)

Uji $t$ ini bertujuan untuk menguji apakah terdapat pengaruh secara parsial atau individu dari masing-masing variabel dependen terhadap variabel independen. Berikut adalah hasil perhitungan berdasarkan data yang diperoleh :

a. Komisaris Independen berpengaruh negatif dan signifikan terhadap manajemen laba

Berdasarkan hasil pengujian yang telah dilakukan diatas yang ditunjukan pada tabel 4.8, variabel komisaris independen memiliki probabiliti sebesar 0,0182 lebih kecil dari p-value sebesar 0,05, maka $\mathrm{H}_{0}$ ditolak yang berarti variabel komisaris independen berpengaruh negatif dan signifikan terhadap manajemen laba.

b. Dewan pengawas syariah berpengaruh negatif dan signifikan terhadap manajemen laba 
Berdasarkan hasil pengujian yang telah dilakukan diatas yang ditunjukan pada tabel 4.8, variabel dewan pengawas syariah yang dihitung dari jumlah rapat dewan pengawas syariah memiliki probabiliti sebesar 0,676 lebih besar dari p-value sebesar 0,05, maka $\mathrm{H}_{1}$ ditolak yang berarti variabel dewan pengawas syariah tidak berpengaruh negatif dan signifikan terhadap manajemen laba.

2. Koefisien Determinasi

Koefisien determinasi $\left(\mathrm{R}^{2}\right)$ digunakan untuk mengukur seberapa baik garis regresi sesuai dengan data actual (goodbess of fit). (Ahadiah Agustina:2018) Koefisien determinasi ini mengukur persentase total variasi variabel dependen (Manajemen Laba) yang dijelaskan oleh variabel independen didalam garis regresi.

Dari tabel 4.8 diatas diperoleh koefisien determinasi atau R Square sebesar 0,147700 artinya 14,7\% variabel terikat yaitu Manajemen Laba (Y) variasinya dapat dijelaskan oleh variabel Komisaris Independen dan Dewan Pengawas Syariah dan sisanya 85,3\% dijelaskan oleh variabel lain.

Berdasarkan hasil pengujian pada tabel 4.8 variabel komisaris independen memiliki probabiliti sebesar 0,0182 lebih kecil dari p-value sebesar 0,05 , maka $\mathrm{H}_{0}$ ditolak yang berarti variabel komisaris independen memiliki pengaruh negatif dan signifikan terhadap manajemen laba. Selanjutnya dapat dilihat nilai koefisien sebesar -0,792735 yang menunjukan hubungan secara negatif, dimana semakin banyak jumlah komisaris independen maka akan semakin kecil tingkat praktek manajemen laba dan pengawasan yang dilakukan komisaris independen semakin berkualitas yang menuntut adanya transparansi dalam pelaporan keuangan perusahaan. Hal ini sesuai dengan hipotesis yang dibangun oleh penulis yang menyatakan bahwa semakin banyak komisaris independen maka akan semakin kecil tingkat praktek manajemen laba. 
Hal ini sehubungan dengan Peraturan Otoritas Jasa Keuangan No. 33/POJK.04/2014 Tentang Direksi Dan Dewan Komisaris Emiten Atau Perusahaan Publik yang menyatakan bahwa tugas Komisaris Independen adalah melakukan pengawasan dan bertanggungjawab atas pengawasan terhadap kebijakan pengurusan, jalannya pengurusan pada umumnya, baik mengenai emiten atau perusahaan publik maupun usaha emiten atau perusahaan publik, dan memberi nasihat kepada direksi. Sehingga, dengan adanya Komisaris Independen dalam suatu perbankan syariah maka praktek manajemen laba akan menurun, karena telah ada badan pengawas yang mengawasi proses pembuatan laporan keuangan dan operasional perbankan syariah yang dilakukan oleh pihak manajemen agar tidak merugikan atau menyesatkan pengguna laporan keuangan tersebut.

Berdasarkan hasil pengujian yang telah dilakukan diatas yang ditunjukan pada Tabel 4.8, variabel dewan pengawas syariah yang dihitung dari jumlah rapat dewan pengawas syariah memiliki probabiliti sebesar 0,676 lebih besar dari p-value sebesar 0,05, maka $\mathrm{H}_{1}$ ditolak yang berarti variabel dewan pengawas syariah tidak memiliki pengaruh negatif dan signifikan terhadap manajemen laba. Selanjutnya dapat dilihat bahwa dewan pengawas syariah memiliki nilai koefisien sebesar 0.006573 yang menunjukan hubungan secara positif, dimana semakin banyak aktivitas rapat dewan semakin tinggi praktek manajemen laba. Hasil ini tidak sesuai dengan hipotesis yang dibangun oleh penulis yang menyatakan bahwa semakin banyak jumlah rapat dewan pengawas syariah maka akan semakin kecil praktek manajemen laba. Hasil ini juga tidak sejalan dengan tugas dan wewenang dewan pengawas syariah yang tercantum dalam PBI No.11/33/PBI/2009 dan SE BI No.12/13/DPbS. 
Kurang mampunya dewan pengawas syariah dalam menurunkan praktek manajemen laba dalam perbankan syariah ialah dikarenakan terdapat beberapa perbankan syariah yang melakukan rapat dewan pengawas syariah kurang dari ketentuan yang diatur melalui Peraturan BI Nomor 11/33/PBI/2009 pasal 49 ayat 1, Dewan Pengawas Syariah wajib menyelenggarakan rapat paling kurang satu kali dalam satu bulan. Namun terlihat dalam statistik deskriptif perbankan syariah melakukan rapat dewan pengawas syariah kurang dari 12 kali, hal ini mengidentifikasikan bahwa jumlah rapat dewan pengawas syariah tidak akan mengurangi peraktek manajemen laba di perbankan syariah.

\section{KESIMPULAN}

Berdasarkan Penelitian ini bertujuan untuk menguji pengaruh komisaris independen dan dewan pengawas syariah terhadap manajemen laba studi pada Bank Umum Syariah di Indonesia selama tahun penelitian 2014-2017. Berdasarkan analisis data yang telah dilakukan secara Parsial dapat ditarik kesimpulan sebagai berikut Komisaris independen yang diukur dengan membandingkan jumlah komisaris independen terhadap jumlah total dewan komisaris terbukti berpengaruh negatif dan signifikan terhadap manajemen laba. Dewan komisaris independen dalam penelitian ini terbukti mampu mengurangi manajemen laba, maka diharapkan untuk mempertahankan agar dapat membatasi praktek manajemen laba. Dewan pengawas syariah yang diukur dengan jumlah rapat dewan pengawas syariah berpengaruh positif dan tidak signifikan terhadap manajemen laba, dari hasil penelitian ini menunjukan bahwa semakin banyak jumlah rapat Dewan pengawas syariah maka akan semakin tinggi praktek manajemen laba. Maka diharapkan dewan pengawas syariah lebih meningkatkan pengawasan terhadap pihak manajemen agar informasi yang terkandung didalam dalam laporan keuangan semakin baik dan berkualitas. Perusahaan 
yang me-laporkan laba lebih besar daripada ekspektasi investor harga sahamnya akan mengalami pening-katan yang signifikan karena investor mempre-diksi perusahaan akan mempunyai masa depan yang lebih baik (Dian agustia, 2013:28).

\section{IMPLIKASI PENELITIAN}

Impilkasi Dewan komisaris independen dalam penelitian ini terbukti mampu mengurangi manajemen laba, maka diharapkan untuk mempertahankan agar dapat membatasi praktek manajemen laba dan semakin banyak jumlah rapat Dewan pengawas syariah maka akan semakin tinggi praktek manajemen laba.

\section{REFERENSI}

Ahadiah Agustina, Pengaruh Peran Komite Audit Dan Dewan Pengawas Syariah Terhadap Earning Management Perbankan Syariah Di Indonesia tahun 2012-2015, (Tesis, 2018).

Danang Suntoyo, Metodelogi Penelitian Akuntansi, (Bandung: Refika Aditama, 2016),

Irham Fahmi, Manajemen Keuangan Perusahaan Dan Pasar Modal. (Jakarta: Mitra Wacana Media, 2014).

Islahuzzaman, Istilah-Istilah Akuntansi dan Auditing ( Bumi Aksara, 2013 ) J.Supranto, Tehnik Sampeling Untuk Survey Dan Eksperimen, (Jakarta: Rineka Cipta, 2007).

Maya Indriastuti. "Analisis Kualitas Auditor dan Corporate Governance Terhadap Maagemen Laba". (Eksistensi ISSN 2085-2401, Vol. IV, No. 2, Agustus 2012). 
Novi Lidiawati dan N.F. Asyik, "Pengaruh Kualitas Audit, Komite Audit,

Kepemilikan Institusional, Ukuran Perusahaan terhadap Managemen Laba". (Jurnal Ilmu dan Riset Akuntansi : Volume 5, No. 5 Mei 2016).

Otoritas Jasa Keuangan (OJK), Statistik Perbankan Syariah September 2018". (2018).

Rahmawati, Teori Akuntansi Keuangan Edisi Pertama (Graha Ilmu: 2012)

Siti Nurjannah, “Pengaruh Ukuran Perusahaan, Kepemilikan Institusional,

Komite Audit dan Dewan Pengawas Syariah terhadap Managemen

Laba". (Universitas Muhammadiyah Surakarta, Skripsi, 2017

Sugiyono, Metode Penelitian Kualitatif, Kuantitatif Dan RED, Cet. Ke 21, (Bandung: Alfabeta, 2014),

Tulus Suryanto. “Manajemen Laba Pada Bank Syariah Di Indonesia: Peran

Komite Audit Dan Dewan Pengawas Syariah". (Kinerja, Volume 18, No.1, Tahun.20014).

Trisnawati, R., Arum S, N., Yuliani, P. K., \& Azizah, A. W. (2019). Pengaruh,

Free Cash Flow, Leverage, Ukuran Perusahaan terhadap Manajemen

Laba Riil dengan Dewan Komisaris Independen sebagai Variabel Moderating (Studi Empiris pada Perusahaan Manufaktur yang Terdaftar di Bursa Efek Indonesia Perode 2015-2017). Seminar Nasional dan The 6th Call For Syariah Paper (SANCALL) 2019.

Agustina, A. (2019). Pengaruh Peran Komite Audit dan Dewan Pengawas Syariah Terhadap Earnings Management Pada Perbankan Syariah di Indonesia. Jurnal Econetica: Jurnal Ilmu Sosial, Ekonomi, dan Bisnis, 1(2).

Jaya, A. I., \& Rasuli, M. (2020). Mekanisme Good Corporate Governance Dan Dewan Pengawas Syariah Pada Kinerja Keuangan Perbankan Syariah Indonesia. CURRENT: Jurnal Kajian Akuntansi dan Bisnis Terkini, 2(1).

Arif, A., \& Purwanto, A. (2020). Analisis Pengaruh Islamic Corporate Governance terhadap Manajemen Laba pada Bank Umum Syariah di 
Indonesia dan Malaysia. Permana: Jurnal Perpajakan, Manajemen, Dan Akuntansi, 12(2).

Ash-Shiddiqy, M. (2019). Determinasi Manajemen Laba Pada Perusahaan Yang Terkategori Daftar Efek Syariah. Jurnal Akuntansi dan Keuangan Islam, 7(2, Oktober).

Azizah, J., \& Erinos, N. R. (2020). Pengaruh Dewan Komisaris, Komite Audit, Dan Dewan Pengawas Syariah Terhadap Kinerja Perbankan Syariah. JURNAL EKSPLORASI AKUNTANSI (JEA), 2(1).

Kodriyah, K., Suprihatin, N. S., \& Octaviani, S. (2017). Peran Dewan Pengawas Syariah, Komite Audit dan Dewan Komisaris Dalam Mendeteksi Praktik Manajemen Laba. JAK (Jurnal Akuntansi) Kajian Ilmiah Akuntansi, 4(2).

Rahmawati, H. I. A. (2013). Pengaruh good corporate governance (GCG) terhadap manajemen laba pada perusahaan perbankan. Accounting Analysis Journal, 2(1).

Nurhayati, E., Yuliafitri, I., \& Amrania, G. K. P. (2019). Analisis Pengaruh Islamic Social Reporting, Ukuran, Dan Jumlah Rapat Dps Terhadap Manajemen Laba Perbankan Syariah Di Indonesi. Banque Syar'i: Jurnal llmiah Perbankan Syariah, 3(1).

Indriastuti, M. (2012). Analisis kualitas auditor dan corporate governance terhadap manajemen laba. Eksistansi (ISSN 2085-2401), 4(2).

Novitasari, T., Hisamuddin, N., \& Maharani, B. (2019). Pengaruh Tata Kelola Perusahaan dan Kualitas Auditor terhadap Manajemen Laba pada Bank Umum Syariah di Indonesia.Jurnal Ekonomi Akuntansi dan Manajemen, 18(2).

Intia, L. C., \& Azizah, S. N. (2021). Pengaruh Dewan Direksi, Dewan Komisaris Independen, Dan Dewan Pengawas Syariah Terhadap Kinerja Keuangan Perbankan Syariah di Indonesia. Jurnal Riset Keuangan dan Akuntansi, 7(2). 
Oktaviani, H. D. (2016). Pengaruh ukuran dewan direksi, proporsi dewan, komisaris independen, dan ukuran komite audit terhadap praktik manajemen laba pada perusahaan farmasi yang terdaftar di BEI Tahun 2009-2014. Jurnal Akuntansi UNESA, 4 (2), 1, 24.

Eivana, E., Widiyanti, A., \& Agustina, Y. (2018). The Effect Of Independent Commissioners, Managerial Ownership, And Audit Committee On Accounting Conservatism. JAR, 2(3).

Agustia, D. (2013). Pengaruh faktor good corporate governance, free cash flow, dan leverage terhadap manajemen laba.Jurnal Akuntansi dan Keuangan, 15(1).

Mokoginta, R. M., Karamoy, H., \& Lambey, L. (2019). Pengaruh Komisaris Independen, Dewan Pengawas Syariah, Kepemilikan Institusional, dan Profitabilitas Terhadap Tingkat Pengungkapan Tanggung-jawab Sosial pada Bank Syariah di Indonesia. JURNAL RISET AKUNTANSI DAN AUDITING" GOODWILL", 9(1).

Agustin, I. \& Filianti D., (2021). The Effect Of Corporate Governance And Financial Performance On Earnings Management Of Sharia Banking Pengaruh Corporate Governance Dan Kinerja Keuangan Terhadap Manajemen Laba Perbankan Syariah. Jurnal Ekonomi Syariah Teori dan Terapan, 8(4).

Mahdalena. Pengaruh Komposisi Dewan Komisaris Independen, Ukuran

Dewan Pengawas Syariah, Ukuran Komite Audit Dan Kepemilikan Institusional Terhadap Pengungkapan Corporate Social Responsibility Berdasarkan Indeks Islamic Social Reporting (ISR) Pada Bank Umum Syariah.

Ningrum, R. A., Fachrurrozie, F., \& Jayanto, P. Y. (2013). Pengaruh Kinerja

Keuangan, Kepemilikan Institusional dan Ukuran Dewan Pengawas Syariah Terhadap Pengungkapan ISR. Accounting Analysis Journal, 2(4). 
Ramadhani, F., Desmiyawati, D., \& Kurnia, P. (2016). Pengaruh Ukuran Perusahaan, Profitabilitas, Leverage dan Ukuran Dewan Pengawas Syariah Terhadap Pengungkapan Islamic Social Reporting (Studi Empiris Pada Bank Umum Syariah Di Indonesia Tahun 2010-2014) (Doctora dissertation, Riau University 